\title{
Cognitive Behavior Therapy Untuk Penurunan Depresi Pada Orang Dengan Kehilangan Penglihatan
}

\author{
Widiya Aris Radiani \\ Fakultas Psikologi, Universitas Mercu Buana Yogyakarta \\ djavuriwiq@gmail.com
}

\begin{abstract}
Abstrak
Penelitian ini bertujuan untuk mengetahui pengaruh Cognitive Behavior Therapy terhadap penurunan tingkat depresi. Hipotesis yang diajukan pada penelitian ini adalah ada perbedaan tingkat depresi antara sebelum dan sesudah diberikan Cognitive Behavior Therapy pada orang dengan kehilangan penglihatan. Subyek adalah 8 orang dengan kehilangan penglihatan. Terdiri dari 4 subyek kelompok eksperimen dan 4 subyek kelompok kontrol dengan menggunakan random assignment dalam menentukan subyek kelompok eksperimen dan kelompok kontrol. Semua subyek diukur dengan menggunakan skala BDI. Acuan skor dalam skala Beck Depression inventory (BDI) yang digunakan dalam penelitian ini adalah depresi sedang (16-23) dan depresi berat (24-63). Pengumpulan data menggunakan wawancara, observasi dan menggunakan analisis uji Mann-Whitney dan Wilcoxon Test. Data dilihat dari melihat Gained score (skor selisih) yang diperoleh dari skor pretest dan posttest. Hasil uji hipotesis pada terapi ini ialah $\mathrm{Z}$ sebesar $-2,323$; $(\mathrm{p}<0,05)$. Berdasarkan analisis tersebut meunjukkan bahwa ada perbedaaan penurunan tingkat depresi antara sebelum dan sesudah diberikan Cognitive Behavior Therapy pada orang dengan kehilangan penglihatan. Tingkat depresi pada kelompok eksperimen lebih rendah dibandingkan dengan kelompok kontrol.
\end{abstract}

Kata kunci: cognitive behavior therapy, depresi

\section{COGNITIVE BEHAVIOR THERAPY FOR DECREASING DEPRESSION ON PERSONS WITH LOSS OF VISION}

\author{
Widiya Aris Radiani \\ Faculty of Psychology, University of Mercu Buana Yogyakarta \\ djavuriwiq@gmail.com
}

\begin{abstract}
This study aims to determine the effect of Cognitive Behavior Therapy toward decreasing of depression level. The hypothesis proposed in this study is that there is a difference in the depression level between before and after given Cognitive Behavior Therapy in people with loss of vision. The subjectswere 8 people with loss of vision. It consist of 4 subjects of the experimental group and 4 subjects of the control group which use random assignment in determining the subjects of the experimental group and the control group. All subjects were measured using a BDI scale. The scoring standards on the Beck Depression Inventory (BDI) scale used in this study are moderate depression (16-23) and major depression (24-63). The data were collected using interviews, observations and Mann-Whitney and Wilcoxon Test analysis. Data viewed from Gained score (score of difference) obtained from pretest and posttest score. The result of hypothesis test on this therapy is $\mathrm{Z}$ equal to 2,323; $(\mathrm{P}<0.05)$. Based on these analyzes, the study shows that there is a difference in depression level decreasing before and after given Cognitive Behavior Therapy in people with loss of vission. The level of depression in the experimental group is lower than that of the control group.
\end{abstract}

Keywords: cognitive behavior therapy, depression 


\section{PENDAHULUAN}

Somantri (2007) menjelaskan bahwa tunanetra merupakan sebutan untuk individu yang mengalami kehilangan penglihatan. Tunanetra dapat disebabkan oleh faktor internal atau faktor dari dalam seperti genetik dan faktor eksternal atau faktor dari luar seperti kecelakaan dan penyakit. Kehilangan penglihatan berarti cara-cara yang biasa dilakukan untuk mengatasi kegiatan umum seperti membaca, menulis, berjalan sesuai dengan arah, bekerja dan lain sebagainya tidak akan dapat dilakukan lagi. Hal ini menyebabkan seseorang harus menyesuaikan diri dengan kebiasaan baru untuk dapat memenuhi tuntutan kehidupannya. Tugas-tugas yang sederhana pun kini mungkin tampak sangat sulit dan berbahaya bagi orang dengan kehilangan penglihatan, terutama jika orang tersebut memiliki pandangan yang negatif tentang ketunetraan seperti memunculkan ketergantungan seumur hidup dan tidak berdaya. Disamping itu, jika orang dengan kehilangan penglihatan berkeyakinan bahwa situasinya tidak akan membaik secara signifikan dalam waktu dekat, maka keputusasaan dan depresi akan dialaminya. Namun jika seseorang dapat melewati masa penyesuaian dirinya dengan tanpa penglihatan berlangsung dengan baik maka ia tidak akan mengalami gangguan psikologisnya dan afeksinya dapat terjaga secara baik pula (Dodds,1993).
Dodds (1993) mengatakan bahwa ketunanetraan yang terjadi dengan tibatiba dapat mengakibatkan depresi, kecemasan, persepsi diri yang tidak tepat, menurunnya tingkat motivasi, rendahnya harga diri dan rendahnya self-efficacy. Keadaan seperti kecemasan dan depresi, umum dialami oleh orang yang baru mengalami kehilangan penglihatan. Dalam keadaan depresi, orang tidak dapat membuat pertimbangan yang sehat, tidak realistis, pesimistik dan prediksinya tentang masa depan suram serta kehilangan harapan. Hal ini diperparah oleh persepsi masyarakat tentang ketunanetraan yang cenderung negatif, yang pada gilirannya individu tunanetra itu sendiri dapat mengembangkan persepsi diri yang tidak tepat. Persepsi yang tidak tepat mengenai ketunanetraan ini membuat banyak individu tunanetra merasa kehilangan harga dirinya. Orang yang kehilangan penglihatannya, menyebabkan kehilangan harga diri dan lebih disebabkan oleh perasaan kehilangan kompetensi yang pernah dimilikinya. Oleh karena itu, penting diberikan adanya suatu tritmen tertentu untuk membantu permasalahan psikologis yang dialami oleh orang dengan kehilangan penglihatan.

Penyesuaian diri terhadap kebutaan menjadi proses panjang yang kemungkinan harus dilakukan melalui beberapa macam cara, tergantung pada temperamen individu itu, pengalamannya 
terdahulu dan caranya mengatasi krisis. Penyesuaian diri ini dapat berhasil dan dapat juga gagal. Jika berhasil melewati masa penyesuaian, individu akan mengembangkan kesejahteraan psikologis yang meliputi penerimaan diri, kemandirian, penguasaan diri terhadap lingkungan, tujuan hidup dan pengembangan dirinya. Sebaliknya jika gagal, individu akan mengalami kesulitan untuk mendapatkan kesejahteraan psikologis dirinya dan akan mengalami depresi (Dodds, 1993).

Ketidaksesuaian antara harapan dengan kenyataan memunculkan emosiemosi negatif pada diri individu antara lain emosi sedih, kecewa, takut, marah dan putus asa. Pengalaman-pengalaman emosional negatif cenderung tidak dimunculkan oleh individu dalam kesadaran karena dipengaruhi strategi mengatasi masalah (coping) yang tidak efektif. Hal ini pada akhirnya menyebabkan munculnya simptomsimptom depresi (Akbar \& Afiatin, 2009).

Beck (1985) menjelaskan bahwa depresi mempunyai gejala utama kesedihan dan perasaan khusus, seperti apatis, merasa sendiri, juga mempunyai gejala psikologik yang lainnya yaitu adanya konsep negatif yang ditunjukkan terhadap dirinya sendiri, regresif, perubahan vegetatif dan perubahan aktivitas. Gejala depresi yang juga biasa ditunjukkan seperti kehilangan minat dan kegembiraan serta berkurangnya energi yang menuju pada meningkatnya keadaan mudah lelah (rasa lelah yang nyata sesudah kerja sedikit saja) dan menurunnya aktivitas (Maslim, 2003).

Menurut Hill (2009) terapi yang dapat diterapkan pada depresi adalah Terapi keluarga, Pelatihan manajemen emosi, Hipnoterapi, Psikoedukasi, Pelatihan berpikir positif dan Cognitive Behavior Therapy. Meskipun banyak terapi yang dapat diberikan pada individu yang mengalami depresi, namun hendaknya dapat memberikan terapi yang sesuai dengan teori dan pendekatan yang dilakukan. Depresi disebabkan oleh adanya skema kognitif atau munculnya distorsi kognitif, rendahnya penilaian terhadap diri sendiri dan tidak adanya keyakinan mengenai masa depannya. Proses kognisi ini akan menjadi jembatan dari proses belajar manusia, dimana pikiran, perasaan dan tingkah laku yang saling berhubungan secara kausal. Dengan demikian pendekatan yang digunakan harus dapat mengatasi kecenderungan yang dialami penderita depresi yaitu dengan menggunakan pendekatan kognitif dan pendekatan perilaku seperti Cognitive Behavior Therapy (CBT).

CBT digunakan untuk memperbaiki distorsi kognitif yang lebih mengutamakan kognisi atau pikiran, proses berfikir dan bagaimana kognisi memengaruhi emosi dan perilaku. Cognitive Behavior Therapy, orang dengan simptom depresi yang awalnya 
mengalami kesedihan, kehilangan semangat, cemas, kurang gembira, berpikir negatif terhadap diri, lingkungan dan masa depan, mempunyai gangguan tidur, menarik diri dari lingkungan, gangguan nafsu makan dan aktivitas menurun berubah menjadi lebih senang, lebih bersemangat, tenang lebih nyaman, menilai positif terhadap diri sendiri, lingkungan dan masa depan, tidur lebih nyenyak, lebih mampu bersosialisasi, nafsu makan dan aktivitas menjadi meningkat. Hal ini juga mempengaruhi cara individu dalam memandang diri dan masa depan sehingga akan memunculkan suatu kekuatan dalam dirinya bahwa dirinya mampu untuk mengatasi permasalahan tersebut (Oemarjoedi, 2004).

Beck (McDowell \& Newel, 1996) mendefinisikan depresi sebagai keadaan abnormal organisme yang dimanifestasikan dengan simptomsimptom seperti: menurunnya mood subjektif, rasa pesimis dan sikap nihilistik, kehilangan kespontanan dan gejala vegetatif (seperti kehilangan berat badan dan gangguan tidur). Depresi juga merupakan gangguan kompleks yang meliputi gangguan afeksi yang menyangkut perasaan dasar (mood), kognisi, motivasi dan komponen perilaku.

Beck (1985) menjelaskan bahwa depresi mempunyai gejala utama kesedihan dan perasaan khusus, seperti apatis, merasa sendiri, juga mempunyai gejala psikologik yang lainnya yaitu adanya konsep negatif yang ditunjukkan terhadap dirinya sendiri, regresif, perubahan vegetatif dan perubahan aktivitas.

Rathus (Lumongga, 2009) menyatakan bahwa orang dengan depresi umumnya mengalami gangguan yang meliputi keadaan emosi, motivasi fungsional, serta kognisi. Atkinson (Lumongga, 2009) juga memaparkan bahwa depresi sebagai suatu gangguan suasana hati yang dicirikan dengan tak ada harapan dan patah hati, ketidakberdayaan berlebihan, tak mampu mengambil keputusan untuk memulai suatu kegiatan, tidak mampu konsentrasi, tidak punya semangat hidup, selalu tegang, dan mencoba bunuh diri. Dengan demikian dapat dikatakan bahwa depresi merupakan gangguan suasana hati yang ditandai oleh kemurungan dan kesedihan yang mendalam serta berkelanjutan sampai hilangnya kegairahan hidup, dan rasa putus asa.

Berdasarkan uraian di atas, dapat disimpulkan secara umum, bahwa depresi merupakan terganggunya fungsi manusia yang berkaitan dengan alam perasaan yang sedih dan gejala penyertanya, termasuk perubahan pada pola tidur dan nafsu makan, psikomotor, konsentrasi, kelelahan, rasa putus asa, tidak berdaya, serta kecenderungan bunuh diri.

Beck (1985) membagi gejala depresi menjadi : 
a. Gejala yang dimanifestasikan secara emosional, yang ditandai : perasaan kesal atau patah hati, perasaan negatif terhadap dirinya, berkurangnya rasa puas, hilangnya rasa kasih dan keterlibatan emosional, derai tangis, hilangnya respon terhadap humor.

b. Gejala yang dimanifestasikan secara kognitif, meliputi rendahnya self evaluation (evaluasi diri), harapan kognitif, mengkritik diri sendiri, menyalahkan diri sendiri, ragu-ragu dalam mengambil keputusan.

c. Gejala yang dimanifestasikan secara motivasional, meliputi hilangnya kemauan, keinginan untuk melarikan diri, menghindar dan menarik diri dari lingkungan, keinginan untuk bunuh diri, meningkatkan ketergantungan seseorang.

d. Gejala yang dimanifestasikan secara fisik dan perencanaan, meliputi hilangnya nafsu makan, gangguan tidur, hilangnya libido dan kelelahan.

Depresi menurut PPDGJ III

(Maslim, 2003) ditandai dengan gejalagejala :

a. Munculnya afek depresi.

b. Kehilangan minat dan kegembiraan.

c. Berkurangnya energi yang menuju meningkatnya keadaan mudah lelah (rasa lelah yang nyata sesudah kerja sedikit saja) dan menurunnya aktivitas.

Menurut DSM IV-TR (2000) gejala utama depresi adalah : a. Suasana hati terdepresi sepanjang hari, hampir setiap hari, seperti yang ditunjukkan baik oleh laporan subyektif (misalnya, perasaan sedih atau kosong) maupun pengamatan yang dilakukan oleh orang lain (misalnya, tampak sedih). Kehilangan minat atau kesenangan yang nyata pada semua, atau hampir semua, aktivitas hampir sepanjang hari.

b. Penurunan berat badan.

c. Insomnia atau hipersomnia.

d. Agitasi atau retardasi psikomotor hampir setiap hari.

e. Kelelahan atau kehilangan tenaga hampir setiap hari.

f. Perasaan tidak berharga.

g. Penurunan kemampuan untuk berpikir dan berkonsentrasi.

h. Pikiran tentang kematian yang berulang dan ide bunuh diri berulang tanpa suatu rencana yang spesifik.

i. Gejala menyebabkan penderitaan secara klinis yang bermakna atau gangguan pada fungsi sosial, pekerjaan, atau fungsi bidang penting lainnya.

Dalam menurunkan tingkat depresi dapat diberikan berbagai macam intervensi seperti terapi keluarga, hipnoterapi, Cognitive Behavior Therapy (CBT) dan psikoedukasi atau bentuk intervensi lain yang dilakukan untuk meningkatkan pemahaman atau ketrampilan sebagai usaha pencegahan meluasnya gangguan psikologis yang 
dialami seseorang setelah menjalani psikoterapi.

Cognitive Behavior Therapy (CBT) dapat diterapkan pada individu yang mengalami depresi. Depresi disebabkan oleh adanya skema kognitif atau munculnya distorsi kognitif, rendahnya penilaian terhadap diri sendiri dan tidak adanya keyakinan mengenai masa depannya. Proses kognisi ini akan menjadi penghubung dalam proses belajar manusia, dimana pikiran, perasaan dan tingkah laku yang saling berhubungan secara kausal.

Pendekatan yang tepat untuk penanganan depresi adalah pendekatan kognitif dan pendekatan behavioral. Terapi yang menggunakan pendekatan kognitif dan behavioral adalah Cognitive Behavioral Therapy (CBT), dimana CBT berguna untuk memerbaiki distorsi kognitif yang lebih mengutamakan kognisi atau pikiran, proses berfikir dan bagaimana kognisi memengaruhi emosi dan perilaku.

Cognitive Behavioral Therapy adalah terapi yang menggabungkan terapi perilaku dan terapi kognitif Albert Ellis dan Aaron T. Beck, yang kemudian dikembangkan oleh Meichenbaum \& Mahoney (Oemarjoedi, 2003). Cognitif Behavior Therapy dapat dijadikan sebagai alternatif terapi yang memiliki metode pendukung yang konsisten dan fakta terdahulu yang efektif dalam menurunkan tingkat depresi (Weersing \& Weisz, 2002).

Cognitive Behavioral Therapy merupakan pendekatan perubahan perilaku yang memokuskan pada target perilaku itu sendiri, kondisi menghilangkan perilaku, kondisi memertahankan perilaku dan faktor-faktor yang menguatkan perilaku itu. Pendekatan ini mengakui pentingnya kognisi individu terhadap perilakunya (Taylor, 1995).

Menurut Horwin (Sudrajat, 2008) Cognitive behavior therapy adalah salah satu bentuk konseling yang bertujuan membantu klien agar dapat menjadi lebih sehat, memperoleh pengalaman memuaskan dan memenuhi gaya hidup tertentu, dengan cara memodifikasi pola pikir dan perilaku tertentu. Pendekatan CBT memusatkan perhatian pada proses berpikir klien yang berhubungan dengan kesulitan emosional dan psikologi klien. Pendekatan ini akan berupaya membantu klien mengubah pikiran-pikiran atau pernyataan diri negatif dan keyakitankeyakinan pasien yang tidak rasional atau mengganti cara-cara berpikir yang tidak logis menjadi logis (Cormier dalam Lubis, 2009).

Berdasarkan penjelasan di atas dapat disimpulkan bahwa prinsip dasar Cognitive Behavior Therapy adalah adanya proses kognitif dan keyakinan bahwa manusia mempunyai potensi untuk berpikir rasional dan irasional. Selain itu, Cognitive Behavior Therapy lebih banyak 
bekerja pada status kognitif masa kini untuk diubah dari negatif menjadi positif dan berusaha menghargai masa lalu sebagai bagian dari hidup klien serta mencoba membuat klien menerima masa lalunya untuk tetap melakukan perubahan pada pola pikir masa kini demi mencapai perubahan untuk masa yang akan datang.

Westbrook, Kennerley \& Kirk (2007) menjelaskan Cognitive Behavior Therapy merupakan terapi yang menggunakan pendekatan kognitif dan perilaku. Dalam terapi ini, fokus diutamakan pada pengubahan pola pikir yang kemudian dapat berpengaruh pada perubahan emosi dan juga perilaku. Behavioral Therapy berfokus pada stimulus (fitur atau kejadian pada lingkungan) dan juga respon (reaksi individu yang terlihat dan terukur). Behavioral Therapy menangani berbagai gangguan mental, terutama gangguan kecemasan dan depresi. Meskipun begitu, beberapa hal menimbulkan ketidakpuasan terhadap Behavioral Therapy, yaitu pengabaian pada proses mental penting seperti pemikiran, keyakinan, interpretasi, imagery dan lainnya. Proses mental tersebut merupakan bagian penting dalam kondisi psikologis manusia. Ketidakpuasan ini mengakibatkan Beck dan beberapa tokoh lainnya melibatkan proses kognitif dan mengembangkan Cognitive Therapy, yang menekankan pada proses pemikiran manusia. Kedua terapi inilah yang menjadi dasar pemikiran dari CBT. Westbrook, Kennerley \& Kirk (2007) menjelaskan mengenai tahap-tahap CBT yaitu:

a. Menemukan pikiran yang negatif

Memberikan pertanyaan langsung untuk menemukan pikiran negatif dan menyadarkan adanya perangkap negatif.

b. Kontruksi pikiran otomatis

c. Relaksasi

d. Keterampilan memecahkan masalah Mengidentifikasi masalah yang dihadapi dan terapis membantu mengidentifikasikan sumber-sumber yang dimiliki oleh subjek.

e. Menetapkan tujuan

f. Latihan kognitif dengan menggunakan imajinasi untuk membayangkan secara detail mengenai tahap-tahap yang akan dilakukan oleh subjek dan konsekuensi yang mungkin dihadapi oleh subjek.

g. Latihan untuk mengubah perilaku terhadap objek.

Berdasarkan penjelasan di atas dapat disimpulkan bahwa Cognitive Behavior Therapy adalah suatu tritmen yang dapat membantu cara berfikir individu agar menjadi lebih rasional dengan menggunakan prinsip dan hukum perilaku. Hal ini bertujuan agar individu mempunyai kemampuan untuk mengenali dan kemudian mengevaluasi atau mengubah cara berfikir, keyakinan dan perasaannya (mengenai diri sendiri dan 
lingkungan) yang salah sehingga individu dapat mengubah perilaku yang maladaptif menjadi adaptif dengan cara memelajari keterampilan pengendalian diri dan strategi pemecahan masalah yang efektif.

Tahapan yang biasa dilakukan dalam CBT adalah menemukan pikiran negatif, menyadarkan adanya perangkap negatif, konstruksi pikiran otomatis, relaksasi, keterampilan memecahkan masalah, menetapkan tujuan, latihan kognitif dan latihan untuk mengubah perilaku terhadap objek. Pendekatan CBT mengakui pentingnya kognisi individu terhadap perilakunya. Oleh karena itu terapi ini berfokus untuk mengubah kognitif subjek terlebih dahulu lalu mengubah perilaku yang bermasalah.

\section{METODE}

Penelitian ini melibatkan variabel bebas/variabel independen yaitu Cognitive Behavior Therapy dan variabel tergantung/variabel dependen yaitu Depresi. Metode pengumpulan data penelitian ini dengan menggunakan observasi, wawancara tak terstruktur dan pengukuran melalui Beck Depression Inventory. Subyek yang dipilih dalam penelitian ini memiliki karakteristik yaitu orang-orang dengan kehilangan penglihatan bukan bawaan minimal 6 bulan kebutaan dan tinggal di Panti Rehabilitasi Penyandang Cacat, Pundong. Individu berusia 18-50 tahun, tingkat pendidikan minimal SMA dan skor pretest $\mathrm{BDI}$ berada pada tingkat depresi sedang sampai berat, dengan skor $>15$.

Teknik analisis data pada penelitian ini yaitu melakukan analisis secara kuantitatif dengan menganalisis perbedaan terhadap tingkat depresi pada orang dengan kehilangan penglihatan, dari pengumpulan pretest dan posttest kelompok eksperimen dengan menggunakan Uji Mann-Whitney dengan gain score, yaitu uji non-parametrik yang digunakan untuk membandingkan kelompok eksperimen dan kelompok kontrol, antara sebelum dan sesudah diberi perlakuan. Sedangkan untuk mengetahui pengaruh terapi pada kelompok eksperimen digunakan teknik Wilcoxon Test.

Selain analisis kuantitatif, pada penelitian ini juga menggunakan analisis kualitatif dari hasil wawancara, observasi dan dokumentasi lainnya sebagai analisis tambahan. Analisis kualitatif dilakukan untuk mengetahui dinamika psikologis pengaruh Cognitive Behavior Therapy terhadap penurunan depresi pada individu dengan kehilangan penglihatan.

Penelitian ini akan menggunakan tipe rancangan pretest-posttest control group design (Azwar, 2004). Rancangan data menggunakan perbandingan selisih skor posttest dengan pretestnya kelompok eksperimen dan kelompok kontrol serta melibatkan dua kelompok subyek. Kedua kelompok terdiri dari individu yang mengalami depresi dimana satu diberi 
perlakukan eksperimental (kelompok eksperimen) dan yang lain tidak diberi perlakuan (kelompok kontrol). Kelompok eksperimen adalah kelompok yang diberikan perlakuan berupa Cognitive Behavior Therapy dan kelompok kontrol dijadikan sebagai pembanding yang tidak mendapatkan terapi. Adapun tahap yang dilakukan pada tahap pengolahan data adalah melalui dua tahap prosedur yaitu pertama mempersiapkan penelitian dengan cara melakukan orientasi kancah dengan mengumpulkan informasi sebanyak mungkin tentang penelitian yang akan dilakukan, pengurusan surat ijin, penyusunan modul terapi dan melakukan professional judgement, mempersiapkan terapis dan melakukan pembekalan serta melatih observer, uji coba modul dan Screening subjek penelitian. Prosedur kedua yaitu masuk pada tahap pelaksanaan penelitian dimana penelitian melakukan pelaksanaan terapi pada kelompok eksperimen selama empat hari di Ruang Psikologi Panti Rehabilitasi Penyandang Cacat, Pundong. Pelaksanaan penelitian dilakukan dengan cara pemberian informed consent penelitian, melakukan pretest, melaksanakan terapi (intervensi Cognitive Behavior Therapy yang diberikan telah dirancang sesuai karakter subjek dengan tahapan menemukan pikiran negatif, menyadarkan adanya perangkap negatif, konstruksi pikiran otomatis, relaksasi, keterampilan memecahkan masalah, menetapkan tujuan, latihan kognitif dan Self Instructional Coping, dilanjutkan dengan pelaksanaan post test, pelaksanaan follow up dan melalui fase waiting list.

\section{HASIL DAN PEMBAHASAN}

Hasil penelitian ini dibagi menjadi dua bagian yaitu analisis kuantitatif dan hasil analisis kualitatif. Hasil analisis menunjukkan bahwa ada perbedaan tingkat depresi antara pretest dan posttest. Artinya ada perbedaan tingkat depresi antara sebelum dan sesudah pemberian intervensi Cognitive Behavior Therapy secara statistik pada kelompok eksperimen. Hal ini menunjukkan bahwa Cognitive Behavior Therapy berpengaruh secara konsisten terhadap penurunan depresi pada orang dengan kehilangan penglihatan.

Pada data analisis kuantitatif yang dilakukan dengan uji U-Mann Whitney dan berdasarkan hasil analisis terhadap uji hipotesis, diketahui bahwa terdapat perbedaan tingkat depresi pada kelompok eksperimen sebelum perlakuan (pretest) dan setelah perlakuan (posttest) pada intervensi Cognitive Behavior Therapy. Pada subyek kelompok eksperimen yang diberikan intervensi Cognitive Behavior Therapy, mengalami penurunan tingkat depresi dibandingkan dengan kelompok kontrol yang tidak diberikan perlakuan berupa intervensi Cognitive Behavior Therapy. Hal ini dapat dilihat dari nilai posttest kedua kelompok (KE dan KK, 
yaitu $Z=-2,323 ; p<0,05)$. Nilai tersebut membuktikan hipotesis yang diajukan peneliti bahwa intervensi Cognitive Behavior Therapy untuk menurunkan depresi dapat diterima.

Data yang digunakan sebagai dasar pengujian hipotesis yaitu data yang diperoleh dari hasil pretest dan posttest data depresi pada orang dengan kehilangan penglihatan baik kelompok eksperimen maupun kelompok kontrol. Mean pretest pada kelompok eksperimen adalah 23,50 dan posttest sebesar 13,00. Mean pretest untuk kelompok kontrol adalah 17,50 dan Mean Posttest sebesar 19,75 .

Analisis lain digunakan untuk melihat perbedaan skor pre test, post test dan follow up pada kelompok eksperimen. Teknik yang dipakai adalah Wilcoxon. Hasil analisis uji beda skor pre test-post test menunjukkan koefisien $\mathrm{Z}$ sebesar 1,826; $p=0,034(p<0,05)$. Hal ini berarti bahwa ada perbedaan tingkat depresi pada orang dengan kehilangan penglihatan pada kelompok ekperimen antara sebelum dan sesudah diberikan Cognitive Behavior Therapy. Skor depresi sebelum diberikan terapi sebesar 23,50, sesudah diberikan terapi mengalami penurunan menjadi 13,00. Jadi dapat disimpulkan bahwa Cognitive Behavior Therapy dapat diberikan untuk menurunkan depresi pada orang dengan kehilangan penglihatan.
Hasil analisis uji beda skor post test-follow up menunjukkan koefisien $\mathrm{Z}$ sebesar -1,826; $\mathrm{p}=0,034(\mathrm{p}<0,05)$. Hal ini berarti ada perbedaan tingkat depresi pada orang dengan kehilangan penglihatan pada kelompok ekperimen antara sesudah terapi dengan fase follow up. Semakin lama, semakin terjadi penurunan skor depresi, dari 13 menjadi 9. Jadi dapat disimpulkan bahwa Cognitive Behavior Therapy berpengaruh secara konsisten terhadap penurunan depresi pada orang dengan kehilangan penglihatan.

Dari hasil analisis data diperoleh data bahwa secara keseluruhan Cognitive Behavior Therapy dapat menurunkan gejala-gejala depresi. Individu yang mengalami depresi umumnya mengalami gangguan yang meliputi keadaan emosi, motivasi, fungsional, dan tingkah laku serta kognisi. Adapun simptom-simptom yang diungkap oleh BDI yaitu motivasional, kognitif, afektif, fisik dan vegetatif. Hal ini bercirikan ketidakberdayaan yang berlebihan akibat dari gangguan depresi seperti adanya gangguan kesehatan yang dialami termasuk ketidaknyamanan, rasa sakit atau penderitaan dan kesulitan dalam melaksanakan aktivitas kehidupan. Keempat subjek menunjukkan ada perubahan yakni kategori simptomsimptom motivasional, emosional, afektif, kognitif dan fisik dan vegetatif. Hasil tersebut didukung pada proses terapi. 
Pada kelompok eksperimen yang mendapatkan terapi menghasilkan skor depresi yang lebih rendah dibandingkan kelompok kontrol yang tidak mendapatkan terapi. Berarti hipotesis penelitian terbukti. Hal ini didukung oleh penelitian sebelumnya yang menyebutkan bahwa Cognitive Behavior Therapy dapat mengurangi tingkat depresi begitu subyek menjadi memiliki tujuan hidup, lebih banyak bersyukur, timbul keyakinan pada diri, semangat yang semakin meningkat, tidak mudah marah, tidur lebih nyenyak, kegelisahan dan perasaan berkurang, nafsu makan menjadi lebih baik dan memiliki harapan untuk hidup lebih baik (Lubis, 2008). Selain itu, penelitian Sharry, Davidson \& McJoughlin (2013) menyimpulkan ada perbedaan signifikan tingkat depresi pada subyek sebelum dan sesudah pemberian program Cognitive Behavior Therapy, tingkat depresi sesudah terapi lebih rendah daripada sebelum terapi. Penelitian yang dilakukan Weersing \& Weisz (2002) juga menunjukkan bahwa Cognitive Behavior Therapy efektif mengurangi simptom depresi yang dialaminya.

Hasil data analisis kualitatif yang diperoleh dari pernyataan subyek, terlihat bahwa subyek kelompok eksperimen mengalami penurunan depresi setelah diberikan intervensi Cognitive Behavior Therapy. Analisis ini dilakukan dengan cara wawancara dan observasi. Observasi dilakukan selama terapi berlangsung.
Observasi yang dilakukan meliputi kondisi secara umum dan prosedur terapi, kondisi peserta selama terapi, dan kondisi terapi. Hasil observasi menunjukkan bahwa ruangan atau lokasi terapi sudah cukup kondusif untuk melakukan terapa dimana ruangan tertutup untuk umum. Kesiapan alat yang digunakan untuk terapi sudah lengkap dan sudah mencukupi. Terapi dilaksanakan selama empat hari, diikuti oleh 4 orang peserta dan dipimpin oleh dua orang terapis dan dibantu oleh dua orang observer. Terapi menggunakan metode ceramah, diskusi kasus dan tugas rumah.

Aspek kondisi peserta pada saat terapi meliputi respon, minat, dan aplikasi terhadap permasalahan yang dihadapi. Respon subjek terdiri dari respon verbal dan respon non verbal. Dari aspek verbal, respon peserta sangat baik, terjalin komunikasi yang baik dan cair diantara peserta dengan terapis. Pada awalnya, beberapa peserta tampak diam, namun saat memasuki sesi aplikatif dari materi pertama, hampir semua orang peserta yang mengeluarkan pendapat tentang materi yang disampaikan. Peserta mampu menyampaikan ide atau gagasan dengan aspirasi dengan baik. Pada aspek non verbal, secara keseluruhan materi terapi mendapat respon yang positif dari peserta, baik materi yang disampaikan melalui ceramah maupun diskusi kasus dapat direspon dengan baik dan antusias oleh peserta. Peserta menunjukkan minat, 
tetapi sesekali dalam sesi materi, beberapa peserta hanya berdiam diri. Aspek minat yang ditunjukkan peserta antusias mengikuti setiap sesi materi yang disampaikan hingga hari keempat terapi. Pada sesi diskusi kasus, peserta terlihat fokus dalam mengerjakan kasus yang diberikan. Peserta berusaha untuk menyampaikan ide dan hasil kerjanya dengan bersemangat.

Berdasarkan penurunan skor depresi pada pretest, posttest dan followup, serta perubahan masing-masing kondisi subjek diketahui bahwa subyek ST pada saat pretest skor tingkat depresi sebesar 20 kategori depresi sedang, setelah diberikan intervensi Cognitive Behavior Therapy (posttest) skor tingkat depresi menjadi 12 kategori depresi ringan. Setelah dilakukan pengukuran seminggu kemudian (follow-up) skor tingkat depresi menjadi 7 kategori normal. Pada subjek RS pada saat pretest skor tingkat depresi sebesar 33 kategori depresi berat, setelah diberikan intervensi Cognitive Behavior Therapy (posttest) skor tingkat depresi menjadi 16 kategori depresi sedang.

Setelah dilakukan pengukuran seminggu kemudian (follow-up) skor tingkat depresi menjadi 10 kategori ringan. Kemudian pada subjek JJ pada saat pretest skor tingkat depresi sebesar 25 kategori depresi sedang, setelah diberikan intervensi Cognitive Behavior Therapy (posttest) skor tingkat depresi menjadi 15 kategori ringan, seminggu setelahnya skor (follow-up) menjadi 12 kategori ringan. Terakhir pada subjek MR pada saat pretest skor tingkat depresi sebesar 16 kategori depresi sedang, setelah diberikan intervensi Cognitive Behavior Therapy (posttest) skor tingkat depresi menjadi 9 kategori normal, seminggu setelahnya skor (follow-up) menjadi 7 kategori normal.

\section{KESIMPULAN}

Hasil analisis menunjukkan ada perbedaan antara pretest dan posttest serta antara posttest dan follow up. Mean pretest pada kelompok eksperimen adalah 23,50 dan skor posttest sebesar 13,00, mean pretest pada kelompok kontrol 17,50 dan skor posttest sebesar 19,75. Hal ini berarti pada kelompok eksperimen ada perbedaan skor depresi dengan kelompok kontrol. Dengan demikian, semua hipotesis penelitian terbukti. Intervensi Cognitive Behavior Therapy berhasil menunjukkan perubahan kategori simptom-simptom motivasional, emosional, afektif, kognitif dan fisik dan vegetatif. Hasil tersebut sebelumnya melalui proses terapi.

Dalam proses Cognitive Behavior Therapy, subyek menentang keyakinan pikiran negatif dan mengubahnya menjadi pikiran positif. Hal ini diakui subyek dapat mengubah perasaan dan pada akhirnya subyek juga menunjukkan perilaku yang lebih positif. Ada perbedaan tingkat depresi antara sebelum 
mendapatkan terapi dan dengan tingkat depresi sesudah mendapatkan terapi. Sebelum diberikan Cognitive Behavior Therapy, 2 subyek memiliki tingkat depresi yang tergolong tinggi dan 2 subyek memiliki skor depresi yang tergolong sedang. Setelah mendapatkan Cognitive Behavior Therapy, semua subyek mengalami penurunan pada tingkat skor depresi. Pada saat posttest, dua subyek memiliki skor depresi yang tergolong ringan, satu subyek memiliki skor depresi yang tergolong sedang dan satu subyek memiliki skor depresi yang normal.

Berdasarkan uraian sebelumnya, dapat disimpulkan bahwa Cognitive Behavior Therapy dapat digunakan untuk menurunkan kategori simptom-simptom depresi pada orang dengan kehilangan penglihatan. Dengan demikian, Cognitive Behavior Therapy ini dapat menjadi salah satu alternatif solusi untuk membantu orang dengan kehilangan penglihatan dalam mengatasi permasalahan yang berkaitan dengan tingkat depresi. Secara umum, sesi-sesi yang disajikan dalam Cognitive Behavior Therapy ini memberikan pengaruh yang efektif terhadap penurunan depresi pada orang dengan kehilangan penglihatan.

Berdasarkan hasil penelitian dan pembahasan, saran yang dapat disampaikan:
1. Kepada orang dengan kehilangan penglihatan yang menjadi subyek penelitian.

Dapat memanfaatkan secara maksimal terapi yang telah diikuti, serta dapat diaplikasikan dalam kegiatan sehari-hari meskipun tanpa bimbingan terapis terutama hal yang dapat membantu subjek secara bertahap mengenali cara penanganan masalah yang selama ini tidak efektif karena dampaknya bagi kondisi emosi selanjutnya.

2. Kepada Petugas Balai Rehabilitasi Terpadu Penyandang Disabilitas (BRTPD)

Cognitive Behavior Therapy perlu dipertimbangkan sebagai salah satu metode yang cukup layak untuk digunakan dalam proses perawatan orang-orang dengan kehilangan penglihatan, khususnya orang yang mengalami depresi, sehingga pihak panti BRTPD perlu menyediakan terapis yang legal dan kompeten dalam CBT.

3. Kepada peneliti selanjutnya

Diharapkan dapat melakukan penelitian lanjutan dengan memperhatikan dan mengatasi kelemahan atau kekurangan dalam penelitian ini khususnya dalam hal:

a. Memperbanyak jumlah dan variasi subyek. Subyek dalam penelitian ini hanya sedikit sehingga disarankan untuk 
peneliti selanjutnya untuk memperbanyak jumlah subyek dan memperbanyak variasi subyek seperti orang dengan kehilangan penglihatan yang mempunyai tanggungan keluarga besar dan beban hidup yang keras.

b. Penekanan dengan cara mengingatkan proses terapi melalui perantara pihak panti atau melalui jaringan telepon agar mengerjakan tugas rumah secara teratur dan rutin, tugas akan membantu subyek dalam memonitor perubahan dan perkembangan terapi yang diikutinya.

c. Memastikan sebaran skor variabel yang diukur adalah seimbang.

d. Perbanyak data kualitatif selama tahap follow up untuk melihat pengaruh terapi.

e. Untuk tempat terapi, sebaiknya tenang, nyaman, tidak bising, sirkulasi udara baik, dapat menciptakan suasana pribadi dimana percakapan tidak bisa didengar orang lain, memungkinkan menciptakan suasana hangat, tidak menegangkan, tempat yang menimbulkan kepercayaan diri pada klien bahwa apa yang akan terjadi dalam ruangan tersebut bersifat pribadi dalam usahanya

\author{
mendapatkan bantuan yang \\ diinginkan.
}

4. Kepada Perguruan TinggiHasil penelitian ini membuktikan bahwa Cognitive Behavior therapy dapat memberi kontribusi yang berarti bagi penurunan depresi. Temuan tersebut tentu diharapkan menjadi sumbangan akademik bagi pengembangan keilmuan dalam bidang psikologi klinis.

\section{DAFTAR PUSTAKA}

Achmad, S. (1988). Hubungan antara perilaku asertif stress dan self esteem dengan depresi pada mahasiswa baru akademi kesejahteraan sosial "AKK" Yogyakarta. Skripsi (Tidak diterbitkan). Yogyakarta: Fakultas Psikologi Universitas Gadjah Mada.

Ahava, W.G., Iannone, C., Grebstein, L., \& Schirling, J. (1998) Is the beck depression inventory reliable over time? An evaluation of multiple test-retest reliability in a nonclinical college student sample. Journal of Personality assessment.70 (2). 222231.

Akbar, Z. \& Afiatin, T. (2009). Pelatihan manajemen emosi sebagai program pemulihan depresi pada remaja korban gempa bumi. Jurnal Intervensi Psikologi. 1.107-124.

American Psychiatric Association. (2000). Diagnostic and statistical manual of mental disorder (DSM)$I V-T R$ (text revision). Washington, DC: APA.

Atkinson, R. L., Atkinson, R. C., \& Hilgard, E. R. (1991). Pengantar 
psikologi, Jilid 2, Edisi 8. Jakarta: Gelora Aksara Pratama.

Azwar, S. (2004). Metode penelitian. Yogyakarta: Pustaka Pelajar.

Beck, A. T. (1985). Depression, causes and treatment. Philadelphia: University of Pennsylvania Press.

Beck, A.T. (2003). Depression: clinical experimental, and theoritical aspects. Philadelphia: University of Pennsylvanie Press.

Corey, G. (1995). Theory and practice of counseling and psychotherapy. Dubuque, Iowa: Kendal Hunt Press.

Davidson, R.J, (2000). Anxiety, depression, emotion. Colombus. Ohio: NetLibrary, In corporated.

Davidson, G \& Neale, J. M. (1997). Abnormal psychology. $7^{\text {th }}$ Ed. New York: John Wiley dan Sons.

Dodds, A. (1993). Rehabilitating blind and visually impaired people: A psychological approach. London: Chapman\& Hall.

Gallo, J.J., Reichel, W., \& Andersen, L.M. (1998). Buku saku: Gerontologi edisi 2. Jakarta: EGC.

Gersang, B. M. (2013). Pengobatan perilaku kognitif untuk depresi postpartum. Jurnal Kesehatan Masyarakat Nasional. 8.1-8.

Ginting, H., Naring, G.,William, M., Srisayekti, W., \& Becker, E.S. (2013). Validitas the beck depression inventory-II indonesia's general population and coronary heart disease patients. International Journal Of Clinical Healt \& Psychology.13(3).235-240.

Hadi, P. 2004. Depresi dan solusinya. Yogyakarta: Penerbit Tugu.
Haeba, N. (2009). Terapi Kognitif Perilaku dan Depresi Pasca Melahirkan. Jurnal Intervensi Psikologi. 1(1).41-75.

Hill, C.E. (2009). Helping skills (facilitating exploration, insight, and action). $\left(2^{\text {nd }}\right)$ ed. Washington: APA.

Indah, V. P. (2012). Menulis pengalaman emosional untuk menurunkan depresi pada perempuan korban kekerasan. Tesis (Tidak diterbitkan). Yogyakarta: Fakultas Psikologi dan Ilmu Sosial Budaya, Universitas Islam Indonesia.

Kaplan, Sadock., \& Grebb. (2010). Sinopsis psikiatri. Jilid dua. Ciputat Tangerang: Binarupa Aksara publisher.

Kode Etik Psikologi Indonesia, (2010). Hasil Kongres XI HIMPSI di Surakarta, Cetakan Pertama. HIMPSI.

Kurniawan, W. (2014). Pengaruh terapi kognitif perilakuan untuk menurunkan gangguan perilaku menentang pada siswa MTS X di Yogyakarta. Tesis (Tidak diterbitkan). Yogyakarta: Magister Profesi Psikologi, Universitas Mercu Buana.

Lestari, A. (1998). Pelatihan berpikir positif untuk menangani sikap pesimis dan gangguan depresi. Jurnal Psikologi. 24(2).1-9.

Lestari, E. W. 2003. Depresi akibat trauma masa kanak-kanak. Skripsi (Tidak diterbitkan). Surakarta: Fakultas Psikologi, Universitas Muhammadiyah Surakarta.

Lubis, N. L. (2008). Aplikasi kognitif tingkah laku (CBT) dengan sokongan sosial terhadap estim kendiri dan depresi penyakit 
kanker. Tesis (Tidak diterbitkan). Fakultas Psikologi, Universitas Sumatera Utara.

Lubis, N. L. (2009). Depresi: Tinjauan psikologis. Jakarta: Prenada media group.

Martin, G \& Pear, J. (2003). Behavior modification, What it is and how to do it, $7^{\text {th }} E d$. New Jersey: Pearson Education International.

Maslim, R. (2001). PPDGJ III. Buku saku. Diagnosis gangguan jiwa. Bagian ilmu kedokteran jiwa. Jakarta: FK Unika Atma Jaya.

Mawandha, G., \& Ekowarni, E. (2009). Terapi kognitif perilaku dan kecemasan menghadapi prosedur medis pada anak penderita leukemia. Jurnal Intervensi Psikologi. 1(1).75-91.

McDowel, I \& Newell, C. (1996). Measuring health: a guide to rating scales and questionnaire (2nd ed). New York: Oxford University Press.

Nevid, J.S., Rathus, S.A., \& Grene, B. (2005). Psikologi abnormal. Jilid dua. Jakarta: Erlangga.

Norman, K. D \& Ynonna, S.L. (2009). Handbook of qualitative research. California: Sage Publication, Inc. 2455. Teller Road Thousand Oaks.

Oemarjoedi, A. K. (2003). Pendekatan cognitive behavior dalam psikoterapi. Jakarta: Penerbit Creatif Media.

Papalia, D.E., Olds, S.W.,\& Feldman, R.D. (2007). Human development (11 $1^{\text {th }}$ edition). USA : McGraw Hill.

Prihanto, S. (1988). Penelitian pendahuluan tentang formulasi to "Learned helplesness". Skripsi (Tidak diterbitkan). Yogyakarta: Fakultas Psikologi Universitas Gadjah Mada.
Retnowati, S. (1990). Terapi kognitif dan terapi perilaku pada penanganan gangguan Depresi. Tesis (tidak diterbitkan). Yogyakarta: Pasca Sarjana Fakultas Psikologi Universitas Gadjah Mada.

Risnawati. (2011). Terapi kognitif perilaku untuk menurunkan depresi pada penderita HIV/AIDS. Tesis (Tidak diterbitkan). Yogyakarta: Fakultas Psikologi, Universitas Gadjah Mada.

Ro'fah, A., \& Muhrisun. (2010). Inklusi pada pendidikan tinggi: best practices pembelajaran dan pelayanan adaptif bagi mahasiswa difabel netra. Yogyakarta : PSLD Universitas Islam Negeri Sunan Kalijaga Yogyakarta.

Ronen. T. (1997). Cognitive devlopment theraphy with children. New York: John Wiley \& Sons.

Rosenthal, N. E., Sack, D.A., \& Gillin, J.C. (1984). Seasonal affective disorder: a description of the syndrome and preliminary findings with light therapy. Archives of General Psychiatry, 41, 72-80.

Sarason, I. G. (1989). Abnormal psychology. 6th Ed. New Jersey: Pentice Hall.

Sharry, J., Davidson, R., \& Mcloughlin, O. (2013). A service-based evaluation of atherapist-supported online cognitive behavioral therapy program for depression. Journal of Medical Internet Research. 15 (6), p1-1. 1p. 5.

Somantri, S. (2007). Psikologi anak luar biasa. Bandung: PT. Refika Aditama.

Stubbings, D. R., Rees, C. S., \& Roberts, L. D. (2013). Comparing in-person to videoconferencebased cognitive behavioral therapy for mood and anxiety disorders: 
randomized controlled trial. Journal of Medical Internet Research. 15 Issue 11, 2-2.

Suwantara, J.R., Lubis, D. U., \& Rusli, E. (2005). Evaluasi beck depression inventory sebagai sarana untuk mendeteksi depresi. Jurnal Psikologi Sosial. 12 (1). 69-77.

Taylor, S. E. (1995). Health psychology, Third edition. Singapore: McGraw Hill,Inc.

Weersing, R. V., \& Weisz, J.R. (2002). Community clinic treatment of depressed youth: Benchmarking usual care against CBT clinical trial. Journal Of Consulting And Clinical Psychology. 70(1).229308.
Westbrook,D., Kennerley, H. \& Kirk, J. (2007). An introduction to cognitive behaviour therapy: Skills and applications. London: Sage.

Yuliza, E. (2012). Terapi kognitif perilakuan religius (Islam) untuk menurunkan depresi pada mahasiswa. Tesis (Tidak diterbitkan). Yogyakarta: Fakultas Psikologi dan Ilmu Sosial Budaya, Universitas Islam Indonesia.

Zakiyah. (2014). Pengaruh dan efektifitas cognitive behavioral therapy (CBT) berbasis komputer terhadap klien cemas dan depresi. E-Journal Kesehatan dan Lingkungan. 1(1). 25-30. 